\title{
Male Breast Cancer: 9 Year Experience and Review in Mid-Western Ireland
}

\author{
K.I. Quintyne ${ }^{*}, 1$, B. Woulfe ${ }^{2}$, A. Merrigan ${ }^{2}$, R.M. Keane ${ }^{2}$, P. O’Brien ${ }^{3}$, S. Finn ${ }^{4}$, R.K. Gupta ${ }^{1,5}$ \\ ${ }^{I}$ Department of Medical Oncology, Mid-Western Cancer Centre, Mid-Western Regional Hospital, Limerick, Ireland \\ ${ }^{2}$ Department of Surgery, Mid-Western Regional Hospital, Limerick, Ireland \\ ${ }^{3}$ Department of Radiology, Mid-Western Regional Hospital, Limerick, Ireland \\ ${ }^{4}$ Department of Pathology, Mid-Western Regional Hospital, Limerick, Ireland \\ ${ }^{5}$ Stokes Research Institute, University of Limerick, Limerick, Ireland
}

\begin{abstract}
Introduction: Male breast cancer (MBC) is a rare condition, which accounts for less than $1 \%$ of all breast cancer diagnoses. Because of this, there is a paucity of focussed work available and most data is derived from female breast cancer studies. Recently, there has been speculation of increased incidence, and we sought to verify this by reviewing our own experience with $\mathrm{MBC}$.

Methods and Materials: A retrospective analysis was designed to include patients seen at our institution from $1^{\text {st }} \mathrm{July}$, 2000 until $31^{\text {st }}$ July 2009 , and information was derived from the patients' records.

Results: Seven (7) patients were found, with an average age of 66.6 years. All patients had discovered their lumps on selfbreast examination as their main presenting complaint, and none noted any other breast symptoms such as mastalgia, bleeding or discharge. Four (4) patients were found to have a family history for malignancy, including female breast, prostate, lung and gastric cancers and Hodgkin lymphoma. Two (2) patients were found to have been exposed to gynaecomastia-inducing agents for extended periods of time. One (1) patient had undergone chest wall irradiation for Hodgkin lymphoma 30 years prior to his diagnosis of MBC. $86 \%$ were diagnosed on histology, with $100 \%$ of these having ductal cancer, with $100 \%$ oestrogen-receptor positivity and $86 \%$ progesterone-receptor positivity.

Conclusion: Patients with $\mathrm{MBC}$ are an uncommon within our institution. Features associated with its presentation compare to what is published within the literature.
\end{abstract}

Keywords: Male breast cancer, MBC, adjuvant therapy, hormonal therapy, BRCA1/2.

\section{INTRODUCTION}

Male breast cancer $(\mathrm{MBC})$ is a reasonably uncommon malignancy and accounts for less than $1 \%$ of all breast cancer diagnoses [1]. Because of the relative rareness of this condition, there is little focussed work available for review, with very few prospective trials actively being undertaken [2]. Consequently, the majority of the current information on this condition has been derived from retrospective analyses spanning many years [3], and therapeutic options have been obtained from results of trials on patients with female breast cancer (FBC).

Recently, there has been renewed interest in MBC, due to reports of increasing incidence being observed [4]. Based on our regional population in Mid-Western Ireland of 361028 , with males accounting for 182296 (based on Central Statistics Office data (www.cso.ie), we see on average two hundred (200) new FBC per annum, and by extrapolation from the literature, we should see two (2) new MBC within the same period. Our experience of patients with all stages of

*Address correspondence to this author at the Department of Medical Oncology, Mid-Western Regional Hospital, Limerick, Ireland;

Tel: 35361482901; Fax: 35361482517; E-mail: keithi.quintyne@hse.ie
MBC is limited, like most single institutions; however, we sought to document incidence, demographics including age, stage of presentation, family history and drug exposure for patients with newly diagnosed $\mathrm{MBC}$ within our region.

\section{MATERIALS AND METHODS}

A retrospective analysis was designed to include patients referred within the period of $1^{\text {st }}$ July, 2000 to $31^{\text {st }}$ July 2009 , and data were derived from several sources within MidWestern Regional Hospital (MWRH):

- $\quad$ Mid-Western Cancer Centre (MWCC) Oncology database

- $\quad$ MWRH case notes

- $\quad$ MWRH pathology reports

- $\quad$ MWRH Breast Multi-disciplinary Meetings

These data were cross-referenced with the National Cancer Registry in Ireland (www.ncri.ie) and revealed that eight (8) patients were diagnosed within the region, but only seven (7) were reviewed at MWRH. 
Table 1. Distribution Showing Age at Presentation, Family and Drug Histories for MBC Patients

\begin{tabular}{|c|c|c|c|c|c|c|c|}
\hline Age at Presentation, Family, Drug and Treatment History & AK & PN & $\mathbf{P M}$ & $\mathbf{J C}$ & PS & KK & $\mathbf{J N}$ \\
\hline Age at presentation (years) & 66 & 76 & 66 & 72 & 71 & 71 & 45 \\
\hline FH for BRCA $1 / 2$ and PTEN & No & No & No & No & No & No & No \\
\hline FH of malignancy & No & No & No & No & Yes & Yes & Yes \\
\hline Exposure to Oestrogens or oestrogen-like agents & No & Yes & No & No & Yes & No & No \\
\hline Previous radiotherapy exposure & No & Yes & No & No & No & No & No \\
\hline
\end{tabular}

\section{RESULTS}

There were seven (7) patients identified. The mean age at presentation was 66.6 years, with standard deviation of 10.5 years, and a range of 44-76 years. The presenting features were reviewed, and all patients were found to have breast lumps detected on self-examination. None of the patients were reported to having mastalgia, bleeding, discharge, skin nodules or inflammatory changes in the breast area. The family, drug and treatment histories were also reviewed and the information is shown in Table 1 . With respect to the family history for BRCA1/2 and PTEN, these patients were reviewed for cancer risk at the National Centre for Genetic Testing, Dublin, Ireland and were found not to have sufficient indications for formal genetic testing. Of the three patients with family history for malignancy, all were within first degree relatives, and the types of malignancies included prostate cancer, lung cancer and Hodgkin lymphoma in $\mathrm{JN}$, gastric cancer in PN and female breast cancer in PS. Of interest two (2) patients were treated with digoxin (oestrogen-like agent, known to cause gynaecomastia with long-term usage) for prolonged period (PN for more than ten years at dose of $0.125 \mathrm{mg}$ and PS for more than six years, at same standard dose of $0.125 \mathrm{mg}$ ) and one (1) patient had undergone thoracic irradiation 30 years previously for Hodgkin lymphoma.

The histopathological features of the tumours were reviewed, and 6 out of the 7 patients had histological confirmation of their diagnoses. One patient's diagnosis was established on clinical and radiological grounds, because of his frail condition. He has subsequently passed away within a few days of his initial assessment. All the sampled tumours were found to be ductal carcinomas, with $100 \%$ of these being oestrogen receptor positive and $86 \%$ of these being progesterone receptor positive and only 1 patient had been tested for her2-neu mutation. The data is shown in Table 2.

The therapeutic options received by the patients were reviewed and the information is shown in Table 3.

The mean follow-up for all patients involved was 19.9 months with a range of $0-60$ months. The survival data for patients was obtained, but given the small numbers of patients the interpretation was not statistically appropriate.

The features as stated in the literature are shown in the Table 4.

\section{DISCUSSION}

$\mathrm{MBC}$ is a relatively rare condition, and therefore it would be extremely difficult to embark on large-scale prospective studies on standards of care, where the results were statistically valid and could be easily reproduced. Several retrospective studies have been published over the years, and this review serves to add a small cohort to those already available in the literature.

The main objective was to elucidate our experience and to see how it compared to established information. Our

Table 2. Distribution Showing Histopathological Features for MBC Patients

\begin{tabular}{|c|c|c|c|c|c|c|c|}
\hline Pathological Features & $\mathbf{A K}$ & PN & PM & $\mathbf{J C}$ & PS & KK & $\mathbf{J N}$ \\
\hline Histological sub-type & Ductal & Ductal & Ductal & Ductal & Ductal & Ductal & N/A \\
\hline Grade & 2 & 2 & 2 & 2 & 2 & 2 & N/A \\
\hline Oestrogen receptor status & Positive & Positive & Positive & Positive & Positive & Positive & N/A \\
\hline Progesterone receptor status & Positive & Negative & Positive & Positive & Positive & Positive & N/A \\
\hline DCIS/LCIS & Present & Absent & Present & Present & Absent & Absent & N/A \\
\hline Her2-neu status & N/A & $\mathrm{N} / \mathrm{A}$ & N/A & $\mathrm{N} / \mathrm{A}$ & N/A & Negative & N/A \\
\hline Tumour size (T status) & $2.0 \mathrm{~cm}(1)$ & $4.5 \mathrm{~cm} \mathrm{(2)}$ & $3.0 \mathrm{~cm}(2)$ & $2.5 \mathrm{~cm}(2)$ & $2.5 \mathrm{~cm} \mathrm{(2)}$ & $1.4 \mathrm{~cm}(1)$ & $5.0 \mathrm{~cm}$ \\
\hline Node count (N status) & $0 / 11(0)$ & $(\mathrm{X})$ & $11 / 21(3)$ & $0 / 11(0)$ & $0 / 20(0)$ & $2 / 13(1)$ & $(\mathrm{X})$ \\
\hline Stage (AJCC) & I & IV & IV & IIA & IIA & IIA & $X$ \\
\hline Nottingham Prognostic Index (NPI) & $\begin{array}{l}2.40 \\
\text { Good }\end{array}$ & N/A & $\begin{array}{l}5.60 \\
\text { Poor }\end{array}$ & $\begin{array}{l}2.50 \\
\text { Good }\end{array}$ & $\begin{array}{l}2.50 \\
\text { Good }\end{array}$ & $\begin{array}{c}4.28 \\
\text { Moderate }\end{array}$ & N/A \\
\hline Affected side & Left & Left & Left & Right & Right & Right & Right \\
\hline
\end{tabular}


Table 3. Distribution Showing the Therapeutic Options for MBC Patients

\begin{tabular}{|c|c|c|c|c|c|c|c|}
\hline Therapeutics Options & AK & PN & PM & $\mathbf{J C}$ & PS & KK & $\mathbf{J N}$ \\
\hline Surgery (Mastectomy and axillary node clearance) & Yes & No & Yes & Yes & Yes & Yes & No \\
\hline Hormonal therapy (Tamoxifen) & Yes & Yes & Yes & Yes & Yes & Yes & No \\
\hline Chemotherapy & No & No & Yes & No & No & Yes & No \\
\hline
\end{tabular}

Table 4. Distribution Showing Features for MBC as Published in the Literature

\begin{tabular}{|l|l|l|}
\hline \multicolumn{1}{|c|}{ Features } & \multicolumn{1}{|c|}{ Results } & \multicolumn{1}{c|}{ Study } \\
\hline \hline Mean age at presentation & 67 years & Giordano [10] \\
\hline Genetic factors & $-\quad$ Family history of female breast cancer & $\begin{array}{l}\text { Rosenblatt } \text { et al. }[14] \\
\text { Kwiatkowska } \text { et al. }[13]\end{array}$ \\
\hline Histological sub-type & BRCA2 mutation & Giordano et al. $[4]$ \\
\hline Oestrogen receptor status & Positive & Giordano [10] \\
\hline Progesterone receptor status & Positive & Giordano [10] \\
\hline Affected side & Left & Scott-Conner et al. $[9]$ \\
\hline Management & Mastectomy with axillary node clearance + hormonal therapy \pm chemotherapy & Giordano [10] \\
\hline
\end{tabular}

results have revealed that the age of presentation for $\mathrm{MBC}$ patients was 66.6 years, and was greater than that of $\mathrm{FBC}$ patients. This finding was comparable to findings in the literature $[5,6]$. The incidence of $\mathrm{MBC}$, like that of most cancers increases with advancing age of the patient, until it reaches a maximum at about the age of 80 years [7].

Our results have also revealed that a painless lump was the main presenting feature for all our patients. This is higher than for FBC, and maybe due to several factors including our sample size or the anatomical nature of the male and female breast or the fact that breast cancer screening is available for women and can potentially detect lesions before they become palpable. This feature also compares with those listed in the published literature [8].

Unlike the published data, where there is a left-sided versus right-sided disease preponderance [9], our results revealed a right sided preponderance. The significance of this is undetermined, but may only reflect our small sample size.

No family history of BRCA1, BRCA2 or PTEN mutations were noted within our cohort, following the preliminary assessments, however $4 / 7$ (57\%) of patients had a family history of malignancy, including prostate cancer, lung cancer, Hodgkin lymphoma, gastric cancer and FBC. Mutations in BRCA1 and BRCA2 have been noted to increase the risk of affected patients developing $\mathrm{MBC}$, although not to the same absolute risk as in patients with FBC [10]. In population-based studies on MBC, BRCA1 mutations were found in $0-4 \%$ patients [11]. Mutations in BRCA2 gene are noted to be more frequent than BRCA1, in patients with $\mathrm{MBC}$, with a range of $4-16 \%$ being noted in population-based studies [12]. MBC in patients with BRCA2 mutations are noted to present at a younger age and $100 \%$ of these are noted to have a poorer outcome, when compared to patients without BRCA2 mutations [13]. It can also be noted that men with a family history of FBC have an increased risk of developing MBC [14], this was seen with one of our patients, but assessing the risk in this case was not possible. One of our patients with MBC, also gave a history 30 years prior of having undergone thoracic irradiation for Hodgkin lymphoma, which has been established as an increasing potential risk [15].

These results have revealed that all patients had ductal carcinoma, this is more likely to be due to the sample size, although review in the literature show that as much as $90 \%$ of $\mathrm{MBC}$ are ductal in origin [4]. This distribution is greater than listed for FBC is approximately $80 \%$ [16]. It was seen that within our dataset of patients with histological information, that oestrogen receptor expression was $100 \%$ and progesterone receptor expression was 86\%. This information compares to the high receptor expression seen in the literature, where oestrogen receptor expression was $90 \%$ and progesterone receptor expression was $81 \%$ [10]. This is higher than seen in FBC, even with adjustment for tumour stage, grade, and age of presentation [10]. There was only information on one patient with her2-neu over-expression within our group, he was not offered adjuvant biological therapy with trastuzumab as there is no official guidance on this. Within the literature, only low levels of her2-neu overexpression is seen in $0-5 \%$ of male patients $[17,18]$. Nottingham prognostic index (NPI) was not formally reviewed in any of the reviews readily available and has only been used in female breast cancer patients, but within our cohort, it was revealed that those with corresponding values, had a good expectation for outcome. This observation very much correlated with the overall survival curves.

This retrospective review is limited by the number of patient's samples found within our unit at MWRH, but it does offer good insight into our patient demographics, that compares with data available in the literature. The question on the role of adjuvant chemotherapy or biological 
manipulation with trastuzumab would be interesting to review, if a larger cohort could be obtained.

\section{REFERENCES}

[1] Jemal A, Tiwari RC, Murray T, et al. Cancer Statistics. CA Cancer J Clin 2004; 54: 8-29.

[2] Bagley CS, Wesley MN, Young RC, et al. Adjuvant chemotherapy in males with cancer of the breast. Am J Clin Oncol 1987; 10: 5566.

[3] Erlichman C, Murphy KC, Elhakin T. Male breast cancer: a 13year review of 89 patients. Am J Clin Oncol 1984; 8: 903-09.

[4] Giordano SH, Cohen DS, Buzden AU, et al. Breast cancer in men: a population-based study. Cancer 2004; 101: 51-7.

[5] Donegan WL, Perez-Mesa CM Carcinoma of the male breast. Arch Surg 1973; 106: 273-79.

[6] Crichlow RW, Kaplan EL, Kearney WH. Male mammary cancer. Ann Surg 1975: 489-94.

[7] Crichlow RW.(Carcinoma of the male breast. Surg Gynecol Obstet 1972; 134: 1011-19.

[8] Goss PE, Reid C, Pintilie M, et al. Male breast cancer: a review of 229 patients who presented to Princess Margaret Hospital during 40 years: 1955-1996. Cancer 1999; 85: 629-39.

[9] Scott-Conner CE, Jochimsen PR, Menck HR, et al. An analysis of male and female breast cancer treatment and survival among demographically identical pair of patients. Surgery 1999; 126: 775780; discussion 780-81.

[10] Giordano SH. A review of the diagnosis and management of male breast cancer. Oncologist 2005; 10: 471-79.

[11] Sverdov RS, Barshck I Bar Sade RB, et al. Genetic analyses of male breast cancer in Isreal. Genet Test 2000; 4: 313-17.

[12] Basham VM, Lipscombe JM, Ward JM, et al. BRCA 1 and BRCA2 mutations in a population-based study of male breast cancer. Breast Cancer Res 2002; 4: R2.

[13] Kwiatkowska E, Teresiak M, Filas V, et al. BRCA2 mutations and androgen receptor expression as independent predictors of outcome of male breast cancer patients. Clin Cancer Res 2003; 9: 4452-59.

[14] Rosenblatt KA, Thomas DB, McTieran A, et al. Breast cancer in men: aspects of familial aggregation. J Natl Cancer Inst 1999; 83: 849-54.

[15] Sasco AJ, Lowenfels AB, Pasker-de Jong P. Review article: epidemiology of male breast cancer. A meta-analysis of published case-control studies and discussion on selected aetiological factors. Int J Cancer 1993; 53: 538-49.

[16] Dixon JM, Page DL, Anderson TJ, et al. Long-term survivors after breast cancer. Br J Surg 1985; 72: 445.

[17] Bloom KJ, Govil H, Gattuso P, et al. Status of HER-2 in male and female breast carcinoma. Am J Surg 2001; 182: 389-92.

[18] Muir D, Kanthan R, Kanthan SC. Male versus female breast cancers. A population-based comparative immunohistochemical analysis. Arch Pathol Lab Med 2003; 127: 36-41.

(C) Quintyne et al.; Licensee Bentham Open.

This is an open access article licensed under the terms of the Creative Commons Attribution Non-Commercial License (http://creativecommons.org/licenses/by-nc/ 3.0/) which permits unrestricted, non-commercial use, distribution and reproduction in any medium, provided the work is properly cited. 